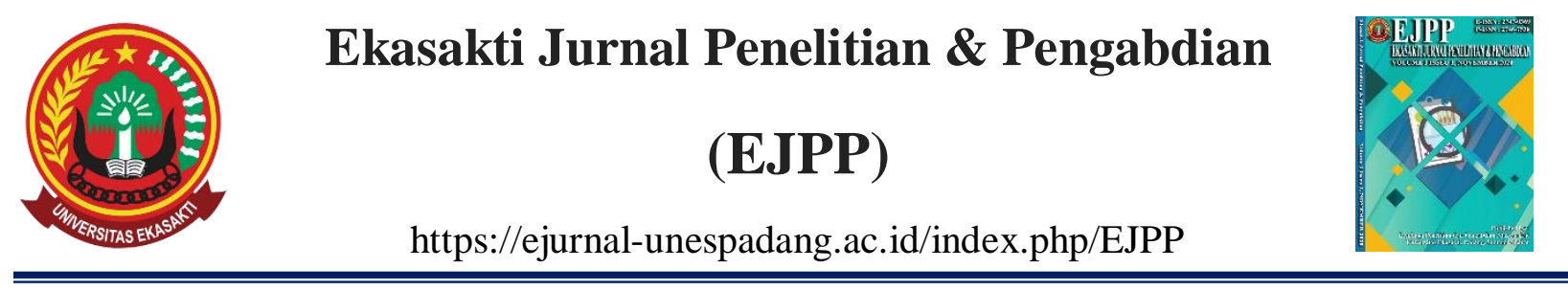

\title{
PENGUATAN PERAN PEREMPUAN DALAM PENGELOLAAN HARTA PUSAKA TINGGI DI MINANGKABAU
}

\author{
Yuhelna $^{1}$, Sri Rahmadani ${ }^{2}$, dan Waza Karia Akbar ${ }^{3}$ \\ 1) Program Studi Pendidikan Sosiologi, STKIP PGRI, Padang, Sumatera Barat \\ Email: lenayuhelna86@gmail.com. \\ 2) Program Studi Pendidikan Sosiologi, STKIP PGRI, Padang, Sumatera Barat \\ Email: srirahmadani118@gmail.com. \\ 3) Program Studi Pendidikan IPS, STKIP PGRI, Padang, Sumatera Barat \\ Email: wazasolok@gmail.com.
}

INFO ARTIKEL

Received : 30/03/2021

Revised : 25/04/2021

Publish : 01/05/2021

Kata Kunci:

Penguatan Perempuan, Konflik Harta Pusaka.

\begin{abstract}
ABSTRAK
Persoalan pengelolaan harta pusaka di Sumatera Barat, khususnya di Minangkabau, kian hari makin sulit terselesaikan secara musyawarah mufakat. Hal ini terlihat dari makin banyaknya laporan kasus sengketa harta pusaka di pengadilan. Tidak dapat dipungkiri salah satu penyebabnya adalah melemahnya atau menurunnya peran atau keterlibatan perempuan dalam pengelolaan harta pusaka yang secara adat telah "diembankan" kepara para perempuan Minangkabau. Menurunnya keikutsertaan perempuan dalam pengelolaan harta pusaka di Minangkabau, tidak terlepas dari minimnya pengetahuan perempuan Minangkabau di era globalisasi ini terhadap status "perempuan Minang". Era globalisasi disinyalir membawa pengaruh yang besar dalam pola fikir perempuan Minang terhadap status dan perannya. Oleh karena itu, perlu peningkatan pengetahuan akan peran perempuan minangkabau dalam pengelolaan harta pusaka sehingga kemudian memunculkan perempuanperempuan yang punya kapasitas dalam pengelolaan harta pusaka tersebut. Pada akhirnya dengan menguatnya peran perempuan dalam pengelolaan harta pusaka, dapat meminimalisir persoalan konflik yang dapat terjadi.
\end{abstract}

\section{ABSTRACT}

Keywords: Strengthening Women, Conflict of Heritage.
The problem of managing inheritance in West Sumatra, especially in Minangkabau, is getting more and more difficult to resolve through deliberation to reach a consensus. This can be seen from the increasing number of cases of inheritance disputes in court. It cannot be denied that one of the causes is the weakening or decreasing role or involvement of women in the management of inheritance which is traditionally "assigned" to Minangkabau women. The decline in women's participation in the management of inheritance in Minangkabau is inseparable from the lack of knowledge of Minangkabau women in this era of globalization regarding the status of "Minang women". The era of globalization is said to have had a big influence on the mindset of Minang women on their status and role. Therefore, it is necessary to increase knowledge about the role of Minangkabau women in the management of 
inheritance so that then it will lead to women who have the capacity to manage these heritage assets. In the end, by strengthening the role of women in the management of inheritance, it can minimize the conflict problems that can occur.

\section{DOI: https://doi.org/10.31933/ejpp.v1i2.354}

\section{PENDAHULUAN}

Indonesia merupakan negara yang kaya, dengan kekayaan alam dan budayanya. Kebudayaan yang beragam diikuti dengan sistem penarikan garis keturunan yang tentunya juga beragam. Salah satu garis keturunan yang adalah matrilineal. Matrilineal diartikan sebagai garis keturunan berdasar garis ibu. Dalam kekerabatan matrilineal harta pusaka merupakan unsur pokok yang harus diwariskan menurut garis keturunan ibu. Harta pusaka menjadi milik bersama dari anggota kaum dan setiap anggota mempunya hak untuk mengusahakan harta tersebut untuk kepentingannya namun tidak bisa dimiliki secara pribadi (Piliang, 2014: 322).

Harta pusaka di Minangkabau dikuasai oleh mamak kepala waris, adalah seorang lakilaki tertua dalam satu kaum yang memimpin dan bertanggung jawab terhadap harta pusaka kaumnya. Mamak kepala waris juga bertindak sebagai hakim bagi kaumnya apabila terjadi perselisihan dan persengketaan mengenai harta pusaka.

Harta pusaka juga merupakan salah satu sarana penunjang ekonomi orang Minangkabau, makin lama makin berkurang, namun demikian peranan harta pusaka sebagai simbol kebersamaan dan kebangggan keluarga dalam sistem kekerabatan matrilineal di Minangkabau tetap bertahan. Harta pusaka sebagai alat pemersatu keluarga masih tetap berfungsi dengan baik namun sebaliknya harta pusaka sebagai milik kolektif atau bersama tidak jarang pula menjadi biang keladi dalam menimbulkan konflik dalam keluarga minang (Amir, 2011:95).

Salah satu konflik yang terjadi di Minangkabau antara ninik mamak sebagai penguasa harta pusaka tinggi dengan perempuan sebagai pemilik harta pusaka tinggi. Seperti kasus galian c yang terjadi di Kecamatan Kuranji, Kelurahan Gunuang Sariak pada Suku Koto, dimana tanah ulayat yang menjadi tempat pemukiman suku tersebut di disewakan untuk dijadikan galian c oleh kaum laki-laki, sehingga menimbulkan kekhawatiran para perempuan.

\section{METODE PENELITIAN}

Pelaksanaan program dilakukan oleh tim terdiri dari ahli sosiologi konlik, pembangunan dan perubahan sosial, dan pendidikan. Program pendampingan dilaksanakan dengan metode pemberdayaan masyarakat dengan konsep pendampingan kelompok sehingga ketika program telah selesai dilaksanakan masyarakat masih bisa melanjutkan kegiatan berikutnya. Metode yang digunakan dalam pelaksanaan program ini adalah "Pemberdayaan Masyarakat" dengan tahapan sebagai berikut:

1. Tahap Perencanaan dan Persiapan

Tahap perencanaan dan persiapan yang dilakukan untuk melaksanakan program ini meliputi: 
a. Identifikasi pertemuan dan pembentukan kelompok kegiatan lapangan.

b. Kunjungan persiapan lapangan.

c. Perumusan tujuan kegiatan lapangan.

d. Penyepakatan waktu dan tempat kegiatan di lapangan.

e. Pembuatan proposal dan menyelesaikan administrasi perijinan pada lembaga yang dilibatkan pada kegiatan lapangan.

f. Melakukan kesepakatan kerjasama dengan lembaga masyarakat setempat.

g. Mempersiapkan peralatan yang dibutuhkan untuk pelaksanaan kegiatan.

h. Penyusunan jadwal dan proses di lapangan.

2. Tahap Pelaksanaan

Melakukan pendampingan dengan melakukan pemetaan masalah dan pemetaan potensi. Pemetaan ini dilakukan secara partisipatif dan melibatkan mereka secara utuh. Pendamping atau pengabdi berada di luar dan perannya adalah sebagai fasilitator. Pemetaan partisiatif dapat dilakukan dengan PRA (Participatory Rural Appraisal). Setelah PRA dilakukan maka dilakukan pengorganisasian masyarakat guna mencapai tujuan bersama. Jika memungkinkan ditunjuk CO (community Organizer di kelurahan tersebut). Setelah ditemukan potensi dilakukan pelatihan keterampilan sesuai dengan potensi yang ada.

3. Evaluasi Kegiatan

Evaluasi dilakukan dengan melakukan pertemuan dengan kelompok wanita dengan metode diskusi dengan anggota terkait dengan permasalahan atau kasus yang pernah mereka alami dan apa solusi yang mereka lakukan dengan kasus tersebut. Setelah itu kita memberikan saran terhadap tindakan yang mereka lakukan.

\section{HASIL DAN PEMBAHASAN}

Kelurahan ini secara geografis, sebelah utara berbatasan dengan Kelurahan Sungai Lareh Kota Padang. Sebelah selatan berbatasan dengan Korong Gadang. Sebelah barat berbatasan dengan Kelurahan Sungai Sapih. Sebelah timur berbatasan dengan Kelurahan Kuranji. Kelurahan Gunung Sarik adalah kelurahan yang terdapat di kecamatan Kuranji, Kota Padang. Kelurahan ini mempunyai luas lebih kurang 1.108 Ha.

Secara administratif, Gunung Sarik adalah kelurahan sedangkan menurut adat ada yang disebut dengan Nagari Pauh Sembilan yaitu ke sembilan kelurahan yang ada di Kecamatan Kuranji:

1. Nagari Sungai Sarik

2. Nagari Sungai Sapih

3. Nagari Kuranji

4. Nagari Korong Gadang

5. Nagari Kalumbuk

6. Nagari Lubuk Lintah

7. Nagari Ampang 


\section{Nagari Anduriang}

9. Nagari Pasar Ambacang

Sembilan nagari tersebut memiliki tuo tapian yaitu:

a. Jambak baduo

b. Guci

c. Jambak Nan Batujuah

d. Caniago

e. Koto Nan Baduo

f. Melayu

g. Tanjuang

h. Sikumbang

i. Koto Batujuah

Artinya masing masing nagari memiliki suku yang dominan yang dikuasai oleh pimpinan suku yaitu penghulu pucuk. Penghulu mempunyai fungsi untuk mengatur anggota kaumnya baik mengenai sako ataupun pusako. Untuk mengenai harta diatur oleh mamak kapalo warih/mamak kepala waris. Tanah di minangkabau bisa dibagi menjadi dua bagian yaitu tanah pusako tinggi dan tanah pusako randah. Tanah pusako tinggi adalah tanah komunal yang dimiliki secara bersama dan dimanfaatkan untuk kaum. Sedangkan tanah pusako randah adalah harta hasil pencaharian orang tua. Harta pusaka rendah bisa menjadi harata pusaka tinggi jika telah diwariskan sebanyak 3 generasi.

Pada dasarnya pengelolaan harta pusaka tinggi di Nagari Gunung Sarik dikelola oleh perempuan dan dimanfaatkan 2/3 bagiannya untuk keluarganya dan 1/3 bagiannya menurut keperluan kaum. Namun menurut informan 1/3 bagian saat ini juga sudah habis. Salah satu habisnya adalah karena harta tersebut dijual atau digadai oleh pengelola atau kemenakan kaum. Salah satu alasan dijual adalah pertengkaran memperebutkan harta pusaka. Salah satu hal yang menyebabkan persengketaan antara penguasaan tanah ulayat adalah klaim tanah atau perebutan tanah. Seperti pepatah adat Minangkabau kusuik sarang tampuo, api nan manyalasaikan, artinya jika tidak bisa lagi diselesaikan dengan baik-baik maka tanah tersebut dibagi dan ada juga yang dijual.

Perempuan di Kelurahan Gunung Sarik ini pertama kali dibina oleh Yayasan Limpapeh pada tahun 1998. Pada tahun ini yayasan ini mengembangkan pemberdayaan perempuan dan advokasi bagi perempuan. Salah satu advokasi yang dilakukan adalah berhubungan dengan kegiatan galian c tanah kaum yang mana perempuan Minangkabau di daerah ini merasa didiskriminasi oleh ninik mamak mereka yang menguasai harta pusako tinggi. Diskriminasi yang mereka alami adalah karena tidak dilibatkan dalam keputusan jual beli tanah, tidak diberikan haknya sebagai ahli waris tanah pusako tingi yang seharusnya adalah milik perempuan.

Pasca gempa pada tahun 2009 banyak lembaga swadaya masyarakat menyusun program di Sumatera Barat. Salah satu lembaganya adalah LP2M (Lembaga Pemberdayaan dan Pengembangan Masyarakat). Lembaga ini juga yang pertama menyentuh perempuan di Kelurahan Gunung Sarik. Program yang diadakan oleh lembaga ini adalah koperasi perempuan. 
Anggotanya adalah perempuan yang berasal dari Kelurahan Gunung Sarik dengan berbagai pekerjaan, seperti ibu rumah tangga, petani, pedagang kecil dan ada yang beternak.

Pada tahun 2010 anggota koperasi ini berjumlah 22 orang, hingga tahun ini menjadi 87 orang. Pembinaan yang dilakukan di koperasi ini diantaranya pembuatan kue kering, cara berternak, budi daya jamur tiram, dan pemberdayaan masyarakat. Saat ini Koperasi Gunung Sarik Saiyo Sudah punya kas sebanyak Rp. 200 juta rupiah. Simpanan pokok koperasi sebesar Rp. 10.000 dan simpanan wajib Rp. 5000. Topik yang sering di bahasa dalam koperasi ini adalah kesehatan keluarga, gender, pelatihan-pelatihan, Industri rumah tangga dan comunity organizer.

Salah satu keunggulan yang dirasakan atau manfaat bagi perempuan selama bergabung dengan koperasi adalah dengan bertambahnya comunity organizer yang semula hanya satu orang menjadi 4 orang. Tugas comunity organizer adalah memfasilitasi anggota dalam untuk lebih berdaya. Orang-orang yang menjadi comunity organizer adalah orang yang sudah mampu berkomunikasi dengan baik. Jadi beberapa orang yang awalnya adalah perempuan yang pemalu, tidak berani mengeluarkan pendapat di depan umum. Namun semenjak bergabung dengan koperasi mereka sudah bisa mengeluarkan pendapat di depan umum.

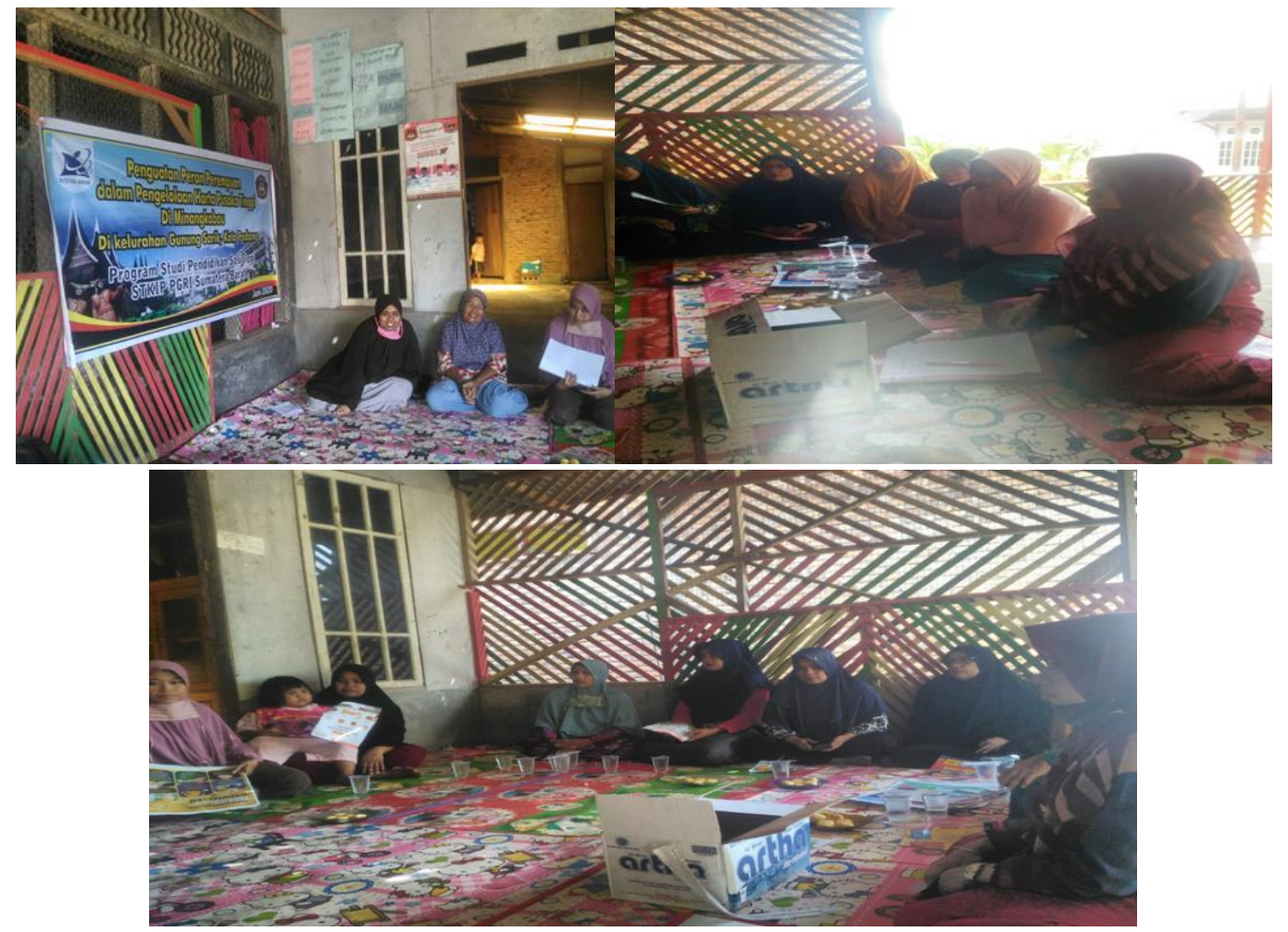

Gambar 1. Pendampingan Kelompok Masyarakat

Selain LP2M ada lembaga lain yang juga mendampingi kelompok masyarakat yaitu KPI (Koalisi Perempuan Indonesia). Peran lembaga ini juga mendukung gerakan perempuan dalam berbagai keadaan atau masalah sosial yang ada di Gunung Sarik. Pada tahun 2010 ketika terjadi hujan lebat dan material sisa galian tanah klai terbawa arus, bahkan ada yang sampai ke rumah 
penduduk. Hal ini membuat masyarakat terutama perempuan perlu melakukan sesuatu agar tidak terkena dampak dari galian c lagi.

Hasil diskusi dan pendampingan menunjukkan bahwa gerakan perempuan yang memperjuangkan hak-hak mereka terhadap tanah ulayat di lokasi tidak berjalan lancar, tetapi menghadapi beberapa tantangan. Tantangan yang dialami oleh perempuan di Kelurahan Gunung Sarik sebagai berikut:

1) Sistem sosial yang tidak mendukung

Sistem sosial yang dimaksud adalah dalam masyarakat Minangkabau perempuan tidak memliki posisi tawar yang baik, sehingga sulit mengemukakan masalah yang mereka alami dan mengemukakan aspirasi mereka terhadap harta pusaka tinggi. Perempuan biasanya diatur oleh ninik mamak mereka dalam pengelolaan harta pusako tinggi.

2) Streotype masyarakat yang kurang baik terhadap perempuan yang sering berkegiatan di luar rumah

Masih adanya anggapan yang kurang baik terhadap perempuan yang sering ikut dalam kegiatan organisasi. Hal ini juga dialami oleh anggota koperasi yang aktif dalam pertemuan dan diskusi, apalagi jika diketahui ada peserta laki-laki dalam pertemuan tersebut. Menurut diskusi ada beberapa masyarakat yang memandang negatif kegiatan perempuan yang aktif dan sering meninggalkan keluraga untuk ikut kegiatan.

\section{KESIMPULAN}

Pelaksanaan program pendampingan terhadap kelompok perempuan di Gunung Sarik membutuhkan program lanjutan karena banyak dari mereka yang tidak paham dengan peran dan fungsi sebagai perempuan di Minangkabau sehingga membutuhkan pendampingan lebih lanjut. Sebaiknya ke depan ada pembentuk pendamingan yang berkelanjutan terhadap kelompok perempuan yang ada di Gunung Sarik terkait dengan peran perempuan dalam pengelolaan harta pusaka tinggi yang ada di Minangkabau.

\section{REFERENSI}

Sjarifoedin, Amir. 2011. Minangkabau Dari Dinasti Iskandar Zulkarnain Sampai Tuanku Imam Bonjol. Jakarta. PT. Gria Media Prima.

Warman, Kurnia. 2006. Ganggam Bauntuak menjadi Hak Milik (Penyimpangan Konversi Hak Tanah di Sumatera Barat, Padang, Andalas University Press.

Zid, Muhammad dan Alkudri, Ahmad Tarmiji.2016. Sosiologi Pedesaan teoretisasi dan Perkembangan Kajian Pedesaan di Indonesia. Jakarta. Rajawali Pers. 